\title{
Penerapan Metode Eksperimen Untuk Meningkatkan Aktivitas Siswa Pada Pembelajaran IPA Kelas V SD Negeri Ngemplak Kecamatan Windusari Kabupaten Magelang Provinsi Jawa Tengah
}

\author{
Mundiyah \\ SD Negeri Ngemplak \\ mundiyah@gmail.com
}

\section{Article History}

received $3 / 12 / 2020$

\begin{abstract}
The lack of student interest in learning science subjects due to the wide and varied scope of learning and the demands of a complete curriculum with content that must be delivered with a limited time allocation resulted in teachers having difficulty in developing learning methods according to student needs so that student learning outcomes were low. This study aims to increase students' learning motivation on the material for the Environment of Our Friends in class V SD Negeri Ngemplak by using the Experimental method in 2019/2020. The research was carried out in three cycles, with the object of research being 19th grade students, consisting of 10 girls and 9 boys. This research was conducted in three cycles, namely planning, action implementation, and reflection. Data collection techniques used are observation and tests. The application of the Experimental method has been proven to improve student achievement, courage, express opinions, and can learn through direct experience. Can enrich the experience with things that are objective and realistic, Can develop students' scientific attitude and can make learning actual.
\end{abstract}

Keywords: experimental method, student activity learning achievement

\begin{abstract}
Abstrak
Kurangnya minat belajar siswa terhadap mata pelajaran IPA dikarenakan cakupan pembelajaranya yang beragam dan luas serta tuntutan kurikulum yang lengkap dengan muatan yang harus disampaikan dengan alokasi waktu yang terbatas mengakibatkan guru kesulitan dalam mengembangkan metode pembelajaran yang sesuai dengan kebutuhan siswa sehingga hasil belajar siswa rendah. Penelitian ini bertujuan untuk meningkatakan motivasi belajar siswa pada materi Lingkungan Sahabat Kita dikelas V SD Negeri Ngemplak dengan menggunakan metode Eksperimen pada tahun 2019/2020. Adapun penelitian ini dilaksanakan dalam tiga siklus,dengan objek penelitian adalah siswa kelas $\mathrm{V}$ yang berjumlah 19 siswa yang terdiri dari 10 anak perempuan dan 9 anak laki-laki. Penelitian ini dilakukan dengan tiga siklus,yaitu perencanaan, pelaksanaan tindakan, dan refleksi. Teknik pengumpulan data yang digunakan adalah observasi dan tes. Penerapan metode Eksperimen terbukti dapat meningkatkan prestasi belajar siswa, keberanian,mengemukakan pendapat,dapat belajar melalui pengalaman langsung. Dapat memperkaya pengalaman dengan hal-hal yang bersifat obyektif dan realistis,Dapat mengembangkan sikap ilmiah siswa dan dapat membuat pembelajaran bersifat actual.
\end{abstract}

Kata kunci: metode eksperimen, aktivitas siswa prestasi belajar

Social, Humanities, and Education Studies (SHEs): Conference Series https://jurnal.uns.ac.id/shes

p-ISSN 2620-9284

e-ISSN 2620-9292 


\section{PENDAHULUAN}

Era globalisasi sebagai wujud dari perubahan dunia mempengaruhi berbagai segi kehidupan. Hal ini ditandai dengan perubahan dalam segala aspekkehidupan serta perkembangan ilmu pengetahuan dan teknologi yang sangat pesat, Dewasa ini, tingkat perkembangan IPTEK di suatu negara semakin meningkat sehingga negaranegara diseluruh dunia berlomba untuk meningkatkan kemajuan negaranya dengan mengembangkan IPTEK.

Pendidikan adalah usaha sadar dan terencana untuk mewujudkan suasana belajar dan proses pembelajaran agar peserta didik secara aktif mengembangkan potensi dirinya untuk memiliki kekuatan spiritual keagamaan, pengendalian diri, kepribadian, kecerdasan, akhlak mulia serta keterampilan yang diperlukan dirinya, masyarakat, bangsa dan negara (Pasal 1ayat 1 UU SIsdiknas tahun 2003).

Kualitas pendidikan dituntut sebagai salah satu sarana mengembangkan ilmu pengetahuan sebgai upaya meningkatkan kualitas pendidikan, maka dilakukan penelitian pendidikan maka, pelajaran IPA di Sekolah Dasar merupakan acuan bagi pengembangan SAINS ditingkat lanjut. Permasalahan yang sering muncul adalah siswa menganggap IPA sebagai pelajaran yang sulit dan kurang nmenarik. Hal inilah yang menyebabkan siswa hanya menjadi obyek pasif yang hanya menerima masukan dan mendengarkan ceramah dari gurunya.

Kurikulum merupakan pedoman dalam proses pembelajaran,oleh karena itu,setiap kegiatan guru dan siswa dalam proses pembelajaran tidak boleh menyimpang dari kurikulum yang merupakan alat untuk mencapai tujuan nasional.

Bahasa merupakan alat komunikasi yang mengandung beberapa sifat yakni sistematik, manasuka, ujar dan komunikatif (PujiSantosa, 2009).

Metode mengajar merupakan salah satu komponen yang harus ada dalam pembelajaran. Pada dasarnya metode mengajar merupakan cara atau teknik yang digunakan guru dalam melakukan interaksi dengan ??siswa ??pada ??saat ??proses pembelajaran ??berlangsung ??(Winata Putra,2003)

Menurut Puji Santoso (2009) Ada beberapa ciri metode yang baik yaitu: (1) mengundang rasa ingin tahu murid; (2) menantang murid untuk belajar; (3) mengaktifkan mental,fisik, dan psikis murid; (4) memudahkan guru (5) mengembangkan kreativitas murid; dan (6) mengembangkan pemahaman murid terhadap materi yang dipelajari

Berdasarkan hasil observasi yang telah dilakukan oleh teman sejawat terhadap pembelajaran awal yang telah dilakukan guru ternyata rendahnya hasil belajar siswa dan rendahnya keaktifan siswa dalam pembelajaran disebabkan oleh metode yang diterapkan guru tidak relevan dengan materi yang diajarkan. Metode pembelajaran yang digunakan adalah ceramah, pada pembelajaran IPA metode tersebut ternyata tidak efektif untuk diterapkan.

Berdasarkan kenyataan di atas, permasalahan tersebut perlu dilakukan perbaikan dan dilakukan penelitian. Atas masalah yang ditemui di kelas $\mathrm{V}$ tersebut guru melakukan Penelitian Tindakan Kelas dengan menerapkan metode Eksperimen untuk membantu siswa dalam memahami materi pelajaran tentang pantun.

Metode Eksperimen dapat diartikan sebagai Pengalaman langsung yang dilaksanakan dengan praktek langsung dilapangan. Berdasarkan kenyataan di atas ,perlu dialakukan metode yang tepat dalam melaksanakan pembelajaran IPA dengan baik dan benar. Untuk meningkatkan aktivitas siswa dalam mengikuti pembelajaran IPA,kiranya metode

Eksperimen perlu dilakukan.siswa kelas V SD Negeri Ngemplak kabupaten Magelang provinsi Jawa Tengah berjumlah 19 orang. Mereka mayoritas belum aktif dalam mengikuti pembelajaran IPA.. Oleh karena itu, untuk perbaikan pembelajaran pada Kompetensi Dasar tersebut perlu dilakukan penelitian tindakan kelas. 


\section{METODE}

Penelitian ini dilakukan dengan menggunakan rancangan Penelitian dan refleksi (Kemmis dalam Kasbolah,1999). Penelitian ini diawali dengan melakukan studi pendahuluan. Studi pendahuluan ini dilakukan untuk mengetahui adanya masalah dalam pembelajaran yang telah dilakukan oleh guru di kelas.

Adapun subjek penelitian adalah guru dan siswa-siswi SD Negeri Ngemplak Tahun pelajaran 2019/2020 yang berlokasi di Dusun Sreyal Desa Ngemplak Kecamatan Windusari Kabupaten Magelang yang berjarak $7 \mathrm{~km}$ dari pusat kabupaten Kota. Adapun mata pelajaran yang diteliti adalah IPA dengan kompetensi. Dasar Mengamati proses terjadinya Siklus Air. Jumlah siswa yang menjadi subjek penelitian berjumlah 19 orang terdiri dari 9 laki- laki dan 10 perempuan, dengan karakteristik sebagian besaran anak petani yang pendidikan orang tuanya paling tinggi tamat SD. Waktu penelitian dimulai dari tanggal 15 Januari sampai dengan 25 Februari 2019.

Data yang dikumpulkan dalam penelitian ini meliputi skor tes dengan bentuk esai pada akhir setiap siklus, objektif, skor bertanya dan menjawab pertanyaan,dan catatan lapangan yang berkaitan dengan aktivitas siswa dalam proses pembelajaran.

Data yang dikumpulkan berdasarkan teknik observasi dan data disajikan dalam bentuk tabel dengan pengelolaan data. Tindakan Kelas (PTK). Penelitian dilakukan dalam tiga siklus yang terdiri atas empat tahap pokok, yaitu perencanaan, pelaksanaan tindakan, pengamatan,

\section{HASIL DAN PEMBAHASAN}

\section{Hasil Pelaksanaan Tindakan Siklus II}

Penelitian ini dilakukan dalam tiga siklus yang bertujuan untuk meningkatkan aktivitas siswa pada pembelajaran Menjelaskan proses terjadinya siklus air. Masingmasing siklus dilakukan dalam satu kali pertemuan (2×35 menit). Berikut ini disajikan hasil pelaksanaan tindakan setiap siklus.

Hasil Pelaksanaan Tindakan Siklus 1 Pembelajaran dilaksanakan oleh guru sebagai kolabolator. Hal ini dilakukan agar kelas tetap terjaga kealamiahannya. Harapannya proses belajar siswa tidak terganggu dan proses pembelajaran di kelas berlangsung optimal.

Berdasarkan hasil observasi yang telah dilakukan oleh teman sejawat bahwa perencanaan yang telah dilakukan oleh guru telah memenuhi persyaratan. Untuk mengajarkan mata pelajaran IPA di kelas V SD Negeri Ngemplak pada kompetensi dasar "Menjelaskan proses terjadinya siklus air", guru telah mempersiapkan beberapa hal diantaranya rencana perbaikan pembelajaran RPP I, alat peraga, lembar pengamatan keaktifan siswa, format penilaian hasil belajar siswa lembar soal terlengkap dengan kunci jawaban serta alat penilaian kemampuan guru yang mencantumkan 6 komponen yang harus diisi oleh teman sejawat. Berdasarkan hasil pengamatan yang telah dilakukan teman sejawat bahwa aktivitas siswa pada proses pembelajaran pada siklus I belum menampakkan peningkatan begitupun dengan nilai tes siswa yang belum mencapai target yang diinginkan. Berikut ini tabel hasil pengamatan aktivitas siswa pada Siklus I.

Tabel 1. Hasil Pengamatan Aktivitas Siswa

Jumlah Siswa

19
Siswa aktif

10
Siswa Tidak aktif

9 
Berdasarkan tabel di atas keaktifan siswa belum mencapai target yang diinginkan keaktifan siswa baru 55\% sedangkan menurut Depdiknas kelas dinyatakan aktif apabila siswa di kelas tersebut keaktifannya mencapai $85 \%$. Begitupun

dengan ketuntasan belajar, pembelajaran dinyatakan tuntas apabila siswa yang memperoleh nilai $>6.5$ mencapai $85 \%$.

Tabel 1. Hasil pengamatan Aktivitas siswa pada Siklus I

\begin{tabular}{cccccc}
\hline No & $\begin{array}{c}\text { Jumlah siswa } \\
\text { Yang Tuntas }\end{array}$ & $\begin{array}{c}\text { Jumlah Siswa } \\
\text { Yang Belum } \\
\text { Tuntas }\end{array}$ & Nilai Rata-rata & Nilai Tertinggi & Nilai Terendah \\
\hline 1 & 12 & 7 & 6,5 & 7 & 5 \\
\hline
\end{tabular}

Ketuntasan belajar pada siklus I baru mencapai $65 \%$. Berdasarkan skor tes dan hasil observasi tentang keaktifan siswa dan guru dalam proses pembelajaran pada siklus 1, guru menyadari bahwa kekurangan pada proses pembelajarannya mengakibatkan kurang berhasilnya pembelajaran. Guru kurang adil di dalam pembagian kelompok diskusi sehingga membuat diskusi tidak berjalan dengan semestinya. Masalah yang diberikan pada siswa kurang menantang, dan guru kurang mengarahkan jalannya diskusi.

Berdasarkan skor tes dan hasil observasi tentang keaktifan siswa dan guru dalam proses pembelajaran siklus 1,maka guru menyadari kekurangan pada proses pembelajarannya yang mengakibatkan kurang berhasilnya pembelajaran. Hal ini desebabkan oleh alasan berikut. Guru kurang adil di dalam pembagian kelompok diskusi sehingga membuat diskusi tidak berjalan dengan semestinya. Pertanyaan kurang menantang. Diskusi kurang terarah. Pada proses pembelajaran di siklus I, skor evaluasi belajar siswa baru mencapai 6,5 (65\%). Adapun keaktifan siswa baru mencapai 55\% dapat dikatakan pembelajaran di siklus I belum berhasil karena belum mencapai target yang telah ditetapkan, hal ini dikarena guru belum bisa mengarahkan jalannya Eksperimen serta masalah yang diamati kurang menantang siswa untuk berbuat aktif dalam proses pembelajaran.

\section{Hasil Pelaksanaan Tindakan Siklus II}

Berdasarkan kekurangan yang terjadi pada siklus I, maka guru akan melakukan perbaikan pada siklus II yaitu dengan cara sebagai berikut :

1. Di awal pembelajaran guru telah mempersiapkan dan membagi kelompok Eksperimen yang anggota tiap kelompok terdiri dari anak pintar, sedang dan kurang pandai. Permasalahan yang akan Dilakukan pengamatan bisa memancing siswa untuk lebih aktif yaitu Menggambar proses siklus air.

2. Guru akan berkeliling dan melihat serta mengarahkan jalannya diskusi. Dengan melakukan perbaikan seperti yang tersebut di atas maka keaktifan siswa mengalami peningkatan hal tersebut dapat dilihat pada table keaktifan siswa di bawah ini. 
Tabel 2. Hasil Pengamatan Aktivitas Siswa

\begin{tabular}{ccc}
\hline Jumlah Siswa & Siswa aktif & Siswa Tidak aktif \\
\hline 19 & 15 & 4 \\
\hline
\end{tabular}

Tabel 3. Hasil pengamatan Aktivitas Siswa pada Siklus II

Keaktifan siswa pada siklus 2 lebih baik. Skor keaktifan siswa sudah mencapai $75 \%$ hasil belajar siswa juga mengalami peningkatan pada siklus 2,sebagaimana dapat dilihat pada tabel 4 berikut ini.

Tabel 4. Hasil Penilaian pada Siklus II

\begin{tabular}{ccccc}
\hline $\begin{array}{c}\text { Jumlah siswa } \\
\text { Yang Tuntas }\end{array}$ & $\begin{array}{c}\text { Jumlah Siswa } \\
\text { Yang Belum } \\
\text { Tuntas }\end{array}$ & Nilai Rata-rata & Nilai Tertinggi & Nilai Terendah \\
\hline 12 & 7 & 7,1 & 8,5 & 5 \\
\hline
\end{tabular}

Berdasarkan tabel di atas dapat dilihat bahwa perolehan skor siswa mengalami peningkatan ketuntasan belajar siswa mencapai $75 \%$. Pada proses pembelajaran siklus II, skor tes siswa yang telah mengalami peningkatan dari 6,5 menjadi 7,1. Untuk mencapai ketuntasan maksimal guru masih perlu mengadakan perubahan.

Diakhir kegiatan Eksperimen guru kurang memberikan Pengarahan dan penghargaan kepada siswa.

Pada siklus 2 proses pembelajaran sudah mengalami peningkatan. Keaktifan siswa sudah berangsur membaik, tetapi menurut teman sejawat masih terdapat kekurangan dalam proses pembelajaran.

1. Guru kurang memantau siswa untuk ketika pengamatan dilaksanakan.

2. Guru kurang memberikan pengarahan maupun pujian pada siswa di akhir siklus.

3. Pada pembelajaran di siklus 2 keaktifan siswa sudah berangsur membaik. Hal ini berdampak pada skor siswa yang mengalami peningkatan dari skor rata- rata 6,5 $(65 \%)$ menjadi 7,1 (75\%) hal ini kaena guru memperbaiki kekurangan pada siklus 1.

Pada proses pembelajaran siklus 2 juga belum mencapai target yang telah ditentukan. Hal ini dikarenakan guru kurang melatih siswa untuk menarik kesimpulan. Pada saat diskusi,diketahui guru kurang memberi pengarahan pada akhir eksperimen berupa pujian dan penghargaan. Hal ini sesuai dengan teknik Eksperimen serta langkah-langkah metode Eksperimen dalam pembelajaran.

Pada pembelajaran di siklus 2 keaktifan siswa sudah berangsur membaik dan berdampak pada skor siswa yang mengalami peningkatan dari skor rata-rata $6,5(65 \%)$ menjadi 7,1 (75\%). Hal ini dikarenakan guru memperbaiki kekurangan pada siklus 1. Pada proses pembelajaran siklus 2 juga belum mencapai target yang telah ditentukan. $\mathrm{Hal}$ ini dikarenakan guru kurang melatih siswa dalam menarik kesimpulan. Pada saat Eksperimen, guru juga kurang memberi pengarahan pada akhir Eksperimen berupa pujian dan penghargaan. Hal ini sesuai dengan teknik Eksperimen serta langkahlangkah eksperimen dalam pembelajaran.

\section{Hasil pelaksanaan Tindakan Siklus III}

Pada siklus 3 ini pembelajaran dititik beratkan pada perbaikan yang sudah dijelaskan pada siklus 2. Pada siklus 3 ini guru merasa bahwa proses pembelajaran 
memang perlu diteliti dan dilakukan perubahan sehingga tahap demi tahap guru harus menyadari apa kekurangan di dalam proses pembelajaran dan kekurangan itu harus diperbaiki. Dengan mempelajari hasil observasi yang telah dilakukan teman sejawat pada siklus 3 ini guru melakukan tindakan perbaikan yang seperti tertulis pada hasil refleksi siklus 2 di atas. Upaya perbaikan yang dilakukan tidaklah sia-sia, terbukti bahwa skor siswa pada siklus 3 mengalami peningkatan yang maksimal. Demikian juga siswa sudah berani mengemukakan pendapat hal ini dapat dibuktikan dengan tabel keaktifan siswan berikut ini.

Berdasarkan nilai pada tabel di atas bahwa keaktifan siswa sudah mencapai $90 \%$. Hal ini menunjukkan bahwa keaktifan siswa sudah mencapai target yang telah ditetapkan Depdiknas (1996). Adapun berdasarkan skor pada tabel 6 di atas dapat diketahui bahwa hasil belajar siswa sudah mencapai ketuntasan yang maksimal. Ketuntasan belajar secara klasikal adalah $90 \%$.

Proses pembelajaran yang berlangsung pada siklus 3 sudah dinyatakan maksimal hal ini dikarenakan guru selalu mempelajari dan berusaha memperbaiki kekurangan pada siklus 1 dan 2 .

Pada siklus 3 proses pembelajaran sudah mencapai target yang diinginkan. Hal ini karena guru selalu memperbaiki kekurangan pada siklus 1 dan 2. Pada siklus 3 ada 2 siswa yang belum tuntas hal ini dikarenakan siswa tersebut memiliki keterbatasan dalam belajar,sering tinggal kelas dan kurang mendapat perhatian dari orang tua.

Tabel 5. Hasil pengamatan Aktivitas Siswa pada Siklus III

\begin{tabular}{cccccc}
\hline No & $\begin{array}{c}\text { Jumlah siswa } \\
\text { Yang Tuntas }\end{array}$ & $\begin{array}{c}\text { Jumlah Siswa } \\
\text { Yang Belum } \\
\text { Tuntas }\end{array}$ & Nilai Rata-rata & Nilai Tertinggi & Nilai Terendah \\
\hline 1 & 17 & 2 & 9,1 & 8,5 & 7 \\
\hline
\end{tabular}

\section{SIMPULAN}

Berdasarkan analisis terhadap data hasil penelitian tindakan kelas ini dapat disimpulkan bahwa penerapan metode Negeri Ngemplak dapat memperbaiki prestasi belajar siswa pada kegiatan akhir pembelajaran.

Berdasarkan kesimpulan di atas penulis menyarankan agar pada saat menyampaikan materi pembelajaran tentang Siklus Air sebaiknya guru menerapkan metode Eksperimen. Dengan demikian,aktivitas siswa pada proses belajar membaik dan prestasi belajar siswa pada kegiatan akhir pembelajaran meningkat.

\section{DAFTAR PUSTAKA}

Strategi Belajar Mengajar. Jakarta: Rineka Cipta.

Dimyati dan Mudjiono. 1999. Belajar Pembelajaran. Jakarta: Rineka Cipta.

Moelono, Anton. 2000. Kamus Besar Bahasa Indonesia. Jakarta: Balai Pustaka.

Purwanto, Ngalim. 1995. Psikologi Pendidikan. Jakarta: Rosdakarya.

Roetiyah, N.K. 2001. Strategi Belajar Mengajar. Jakarta: Rineka Cipta.

Sukmadinata, Nana Syaodih. 2005. Metode Penelitian Pendidikan. Bandung:

Rosdakarya.

Winkel 1996. Psikologi Pengajaran. Jakarta: Gramedia Widiasarana Indonesia.

Wiriatmojo, Rochiati. 2005. Metode Penelitian Tindakan Kelas. Bandung: Remaja Rosdakarya. 